\title{
Effect of Seed Mycoflora on Mungbean Seed Health with Respect to Seed Germination and Seedling Vigour
}

\author{
Rameela I. Chaudhari*, Vikram R. Gohel and Tarun K. Mandaviya \\ Department of Plant Pathology, B. A. College of Agriculture, Anand Agricultural University, \\ Anand-388110, Gujarat (India) \\ *Corresponding author
}

\begin{tabular}{|c|c|}
\hline & A B S T R A C T \\
\hline $\begin{array}{l}\text { Mungbean, } \\
\text { Germination, Seedling } \\
\text { length, Seedling } \\
\text { vigour index, Per cent } \\
\text { discolouration } \\
\text { intensity }\end{array}$ & \multirow{3}{*}{$\begin{array}{l}\text { Mungbean is grown principally for its protein content. Seed borne mycoflora affect the } \\
\text { germination and vigour of seeds. Seed health is an important factor in the control of } \\
\text { diseases, since an infected seed is less viable, has low germination, reduced vigour and } \\
\text { reduced yield. Total five cultivars viz., GM 3, GM 4, GAM 5, K } 851 \text { and Meha and eight } \\
\text { seed mycoflora (fungal species) namely, Alternaria alternata, Fusarium oxysporum, } \\
\text { Aspergillus niger, A. flavus, A. terreus, A. fumigatus, Macrophomina phaseolina and } \\
\text { Phoma sp. were isolated and used for study. Result revealed that the minimum seed } \\
\text { germination was observed in the seed treated with Macrophomina phaseolina (55.55\%). } \\
\text { The significantly lowest seedling length was observed in cultivar Meha ( } 4.81 \mathrm{~cm}) \text {. Among } \\
\text { all the tested fungus, seedling vigour index (SVI) was highly influenced by Macrophomina } \\
\text { phaseolina (229.93). The lowest seedling vigour index was found in cultivar Meha } \\
\text { (302.48). The highest per cent discolouration intensity was observed by Macrophomina } \\
\text { phaseolina (85.25) in cultivar Meha. }\end{array}$} \\
\hline Article Info & \\
\hline $\begin{array}{l}\text { Accepted: } \\
\text { 15 June } 2018 \\
\text { Available Online: } \\
10 \text { July } 2018\end{array}$ & \\
\hline
\end{tabular}

\section{Introduction}

Mungbean (Vigna radiata (L.) Wilczek) is one of the most important and extensively cultivated pulse crop. It is commonly known as "mung", "green gram" or "mungbean". It belongs to the family leguminaceae and native to India and Central Asia. The area under mungbean cultivation in India is 3.019 million hectares and production is 1.503 million tonnes (Anon., 2016). It is widely cultivated throughout the Asia including India, Pakistan, Bangladesh, Sri Lanka, Thailand, Cambodia, Vietnam, Indonesia, Malaysia and South
China. Major mungbean producing states in India are Odisha, Maharashtra, Andhra Pradesh, Madhya Pradesh, Gujarat, Rajasthan and Bihar. The area under mungbean in Gujarat is 0.129 million hectares and production is 0.061 million tonnes (Anon., 2016). Major mungbean producing districts in Gujarat are Kutchh, Banaskantha, Sabarkantha, Mahesana, Surendranagar and Ahmedabad. However, it is grown in very large areas during summer season in Kheda, Vadodara and Panchmahals districts and with the availability of irrigation water through Narmada project, area under mungbean has 
been increase in Central and North Gujarat. Pulse production is very low and become challenging problem against the requirement of increasing population of our country. The pulse availability per capita was $69.9 \mathrm{~g}$ in 1951, by decreasing in 1971 it comes to $50 \mathrm{~g}$ and in 1982 remained only $40 \mathrm{~g}$, and in 2005 it was $27 \mathrm{~g}$ and in 2012 it was $41.7 \mathrm{~g}$. The availability of pulse is very negligible at present as against required $85 \mathrm{~g} /$ day/capita for balanced diet. To recover this deficit of production, it is a high time to cultivate pulse crops scientifically with increasing area.

The composition of mungbean seed is approximately 25.0 to $28.0 \%$ protein, 1.0 to $1.5 \%$ oil, 3.5 to $4.5 \%$ fiber, 4.5 to $5.5 \%$ ash and 62.0 to $65.0 \%$ carbohydrate on a dry weight basis (Singh et al., 1970; Tsou et al., 1979). "Seed health refers primarily to the presence or absence of the microorganisms of various kinds (ISTA, 1985). It has been realized by time and again that seed health, a paramount importance for crop stand and yield returns. Hence, aptly quoted "A healthy seed leads to a healthy harvest'”.

The infected seed fail to germinate or seedlings and plants developed in the field from infected seeds may escape early infection but may often be infected at the later stage of growth. Besides, pathogens can spread over a long distance and uninfected field may be infected by the seeds which carries different pathogens (Fakir et al., 2001). Seed health is an important factor in the control of diseases, since an infected seed is less viable, has low germination, reduced vigour and reduced yield (Van Gastel et al., 1996). A large number of mycoflora was reported to be associated with the mungbean seeds. Alternaria sp., Fusarium oxysporum, Fusarium solani, Fusarium equiseti, Myrothecium roridum, Drechslera sp., Aspergillus flavus, A. niger and Macrophomina phaseolina were found in germinating seeds and seedlings of mungbean (Bakr and Rahaman, 2001).
Presently, the information the Effect of seed mycoflora on mungbean seed health with respect to seed germination, seedling length, seedling vigour index and per cent discolouration intensity. Keeping this in view, present investigation was envisaged.

\section{Materials and Methods}

The present investigation on "Status of seed mycoflora of mungbean [Vigna radiata (L.) Wilczek] cultivars and their management" included effect of seed mycoflora on mungbean seed respect to seed germination, seedling length, seedling vigour index and per cent discolouration intensity was under taken at the Department of Plant Patholology, B. A. College of Agriculture, Anand Agricultural University, Anand during the year 2017-2018.

\section{Effect of seed mycoflora on seed health}

Total five mungbean cultivars viz., GM 3, GM 4, GAM 5, K 851 and Meha and eight seed mycoflora (fungal) species namely, Alternaria alternata, Fusarium oxysporum, Aspergillus niger, A. flavus, A. terreus, A. fumigatus, Macrophomina phaseolina and Phoma sp. were isolated and used for the study. Following methods were used to study the influence of seed mycoflora on seed health in respect to seed germination and seedling vigour index.

\section{Seed inoculation with seed mycoflora}

Mungbean seeds of five cultivars were artificially inoculated with each of the seed mycoflora separately. Seeds moistened by sterilized water were mixed thoroughly with 10 days old respective fungal culture growth obtained on PDA at $25 \pm 2^{\circ} \mathrm{C}$. Such treated seeds were kept in Petri plates for overnight at $25 \pm 2^{\circ} \mathrm{C}$, and then these seeds were used for further study and recording seed germination, seedling vigour index and assessment of seedling abnormalities. 


\section{Effect on seed germinability}

Effect of seed mycoflora on seed germination was tested by paper towel method. One sheet of germination paper was wetted by distilled water. Seeds (25) of respective mungbean cultivars inoculated with respective seed mycoflora were placed on first sheet evenly in a row. Second sheet of germination paper was placed on first sheet. Second sheet was wetted carefully. Both sheets were rolled along with wax coated paper. The rolled paper were incubated in seed germinator at $25^{\circ} \mathrm{C}$ for 7 days. At the end of incubation, rolled towel papers were carefully opened. Germinated and ungerminated seeds were counted treatmentwise and variety-wise. Healthy seeds without inoculation of seed mycoflora were kept as control. Four repetitions each of 100 seeds were maintained for each of the treatments. Seedling length of germinated seeds were recorded.

\section{Seedling Vigour Index (SVI)}

Seedling vigour index was calculated on the basis of seed germination and seedling length (root length and shoot length) after seven days of incubation (Abdul-Baki and Anderson, 1973).

Vigour Index $(\mathbf{V I})=($ Mean root length + Mean shoot length) $\times$ Seed germination $(\%)$

\section{Assessment of seedling abnormalities by discolouration grade}

The symptoms were observed after ten days of incubation of inoculated seeds of respective cultivars by using paper towel method. Each of the developing seedling was observed visually critically and with the help of magnifying hand lens for seedling discolouration due to seed mycoflora infection on developing seedlings. Seedling discolouration was categorized using 0-4 rating scale. Four repetitions each of 25 seeds were evaluated for each of the treatments.

Following formula was used to calculate the percent discoloration intensity (Wheeler, 1969).

$\mathrm{PDI}=$

Sum of total ratings $\times 100$

No. of seedlings examined $\times$ Maximum rating scale

\section{Results and Discussion}

\section{Effect of seed mycoflora on seed germination}

The seed germination was influenced by seed mycoflora. The result revealed that the lowest seed germination was found in cultivar Meha (58.72\%) followed by cultivar GM 4 (65.56\%) and cultivar GM 3 (73.50\%). Significantly highest seed germination was observed in cultivar GAM $5 \quad(78.42 \%)$ which was statistically at par with cultivar $\mathrm{K} 851$ (78.11\%) (Table 2). All the tested fungus reduced the seed germination on the different mungbean cultivars as evident from reduced germination per cent as compared to control. Macrophomina phaseolina, Fusarium oxysporum, Aspergillus flavus, Aspergillus niger, Aspergillus terreus, Alternaria alternata, Apergillus fumigatus, Phoma sp. and control(untreated) showed average germination per cent 55.55, 56.60, 66.15, 67.90, 72.0, 73.15, 75.75, 81.50 and 89.75, respectively (Plate 1 to 5). Among all the fungus, the minimum seed germination was observed in the seed treated with Macrophomina phaseolina $(55.55 \%)$ which was statistically at par with Fusarium oxysporum $(56.30 \%)$. Maximum germination per cent was observed in Phoma sp. (81.50\%) as compared to control (89.75\%). Seed germination of mungbean seed was decreased 
due to infestation of selected dominant seed mycoflora. Similar results were also found by Deshmukh (2012) who reported that maximum seed germination $(91.95 \%)$ was reduced in the seeds inoculated with mixture of all fungi. $M$. phaseolina also caused comparatively more effect on germination $(51.18 \%)$. The loss in germination in $A$. alternata $(40.77 \%)$ and $C$. capsici $(36.48 \%)$ were medium while it was very less (8.41$21.80 \%$ ) in rest of the fungal inoculated seeds. Utobo et al., (2011) also reported that Fusarium invade the seed coat, endosperm and embryo resulting in failure of germination. Sinha and Prasad (1981) also reported that adverse effect on seed germination due to Alternaria alternata, Bortyodiplodia theobrome, Curvularia lunata, Fusarium moniliforme and Macrophomina phaseolina.

\section{Effect of seed mycoflora on seedling length}

Five different mungbean cultivars were assessed for seedling length influenced by seed mycoflora was carried out by paper towel method. The data are presented in Table 3. Results showed that all test fungi significantly reduced seedling length as compared to control (without inoculation of fungi) (Plate 6). Significantly lowest seedling length was observed in cultivar Meha $(4.81 \mathrm{~cm})$ followed by cultivar GM $4(5.76 \mathrm{~cm})$ and cultivar K 851 $(5.86 \mathrm{~cm})$. The highest seedling length was observed in cultivar GAM $5(6.38 \mathrm{~cm})$ which was statistically at par with cultivar GM 3
$(6.21 \mathrm{~cm})$. Eight fungus significantly affected on seedling length during assessment on paper towel method. Among them, lowest seedling length was observed in Macrophomina phaseolina $(3.95 \mathrm{~cm})$ followed by Aspergillus flavus $(4.88 \mathrm{~cm})$, Fusarium oxysporum (4.96 $\mathrm{cm})$, and Aspergillus niger $(5.05 \mathrm{~cm})$. The seedling length was least affected by Phoma sp. $(7.11 \mathrm{~cm})$ as compared to control $(8.19$ $\mathrm{cm})$. The finding was supported by Sadhu (2014), who studied the effect of six dominant seed-borne fungi on seedling emergence, shoot and root length of green gram and reported that the fungi Aspergillus niger and Drechslera tetramera affected most adversely the seedling emergence $(40 \%$ each, control $90 \%)$, shoot length $(5 \mathrm{~cm}$, control $14 \mathrm{~cm})$, and root length $(5 \mathrm{~cm}$, control $10 \mathrm{~cm})$, respectively. Root length was not affected in case of seeds treated with $R$. stolonifer and $A$. fumigatus but more root length $(12 \mathrm{~cm})$ was recorded in case of seeds infested with $F$. moniliforme over control.

\section{Effect of seed mycoflora on seedling vigour index}

Seedling vigour index (SVI) was influenced by individual seed mycoflora associated with different cultivar of mungbean are presented in Table 4. Results indicated that each of seed mycoflora significantly reduced SVI of all cultivars over the control. The highest seedling vigour index was observed in cultivar GAM 5 (511.44).

Table.1 Discolouration grade for the assessment of seedling abnormalities

\begin{tabular}{|c|l|}
\hline Rating Scale & Description \\
\hline $\mathbf{0}$ & Healthy seedling (no visible symptoms) \\
\hline $\mathbf{1}$ & Discolouration of 1-10\% part of seedling \\
\hline $\mathbf{2}$ & Discolouration of $11-25 \%$ part of seedling \\
\hline $\mathbf{3}$ & Discolouration of $26-50 \%$ part of seedling \\
\hline $\mathbf{4}$ & Discolouration of $>50 \%$ part of seedling \\
\hline
\end{tabular}


Table.2 Seed germination of mungbean cultivars as influenced by seed mycoflora

\begin{tabular}{|c|c|c|c|c|c|c|c|c|c|c|}
\hline \multirow{3}{*}{ Cultivars } & \multicolumn{9}{|c|}{ Seed germination $(\%)$} & \multirow{3}{*}{$\begin{array}{c}\text { Mean } \\
\text { (C) }\end{array}$} \\
\hline & \multicolumn{9}{|c|}{ Fungi } & \\
\hline & $\begin{array}{c}\text { Alternaria } \\
\text { alternata }\end{array}$ & $\begin{array}{l}\text { Fusarium } \\
\text { oxysporum }\end{array}$ & $\begin{array}{c}\text { Aspergillus } \\
\text { niger }\end{array}$ & $\begin{array}{l}\text { Aspergillus } \\
\text { flavus }\end{array}$ & $\begin{array}{c}\text { Aspergillus } \\
\text { terreus }\end{array}$ & $\begin{array}{l}\text { Aspergillus } \\
\text { fumigatus }\end{array}$ & $\begin{array}{c}\text { Macrophomina } \\
\text { phaseolina }\end{array}$ & $\begin{array}{l}\text { Phoma } \\
\text { sp. }\end{array}$ & Control & \\
\hline GM 3 & 77.50 & 64.00 & 70.50 & 67.75 & 68.25 & 76.25 & 67.25 & 79.25 & 90.75 & 73.50 \\
\hline GM 4 & 67.75 & 36.50 & 62.25 & 63.50 & 64.50 & 66.25 & 61.50 & 82.50 & 85.25 & 65.56 \\
\hline GAM 5 & 80.00 & 69.25 & 73.50 & 75.00 & 75.75 & 78.25 & 71.25 & 87.25 & 95.50 & 78.42 \\
\hline K 851 & 85.50 & 67.50 & 75.25 & 76.50 & 81.00 & 84.25 & 56.25 & 84.25 & 92.50 & 78.11 \\
\hline Meha & 55.00 & 45.75 & 58.00 & 48.00 & 70.50 & 73.75 & 21.50 & 74.25 & 81.75 & 58.72 \\
\hline \multirow[t]{2}{*}{ Mean $(F)$} & 73.15 & 56.60 & 67.90 & 66.15 & 72.00 & 75.75 & 55.55 & 81.50 & 89.75 & \\
\hline & $\mathbf{C}$ & $\mathbf{F}$ & C X F & & & & & & & \\
\hline $\mathrm{S} \mathrm{Em} \pm$ & 0.64 & 0.85 & 1.92 & & & & & & & \\
\hline $\mathrm{CD}$ at $5 \%$ & 1.78 & 2.38 & 5.32 & & & & & & & \\
\hline $\mathrm{CV} \%$ & 5.42 & & & & & & & & & \\
\hline
\end{tabular}

(Note: $\mathbf{C}=$ Cultivar, $\mathbf{F}=$ Fungi) 
Table.3 Seedling length of mungbean cultivars as influenced by seed mycoflora

\begin{tabular}{|c|c|c|c|c|c|c|c|c|c|c|}
\hline \multirow[t]{3}{*}{ Cultivars } & \multicolumn{9}{|c|}{ Seedling length $(\mathrm{cm})$} & \multirow{3}{*}{$\begin{array}{c}\text { Mean } \\
\text { (C) }\end{array}$} \\
\hline & \multicolumn{9}{|c|}{ Fungi } & \\
\hline & $\begin{array}{c}\text { Alternaria } \\
\text { alternata }\end{array}$ & $\begin{array}{l}\text { Fusarium } \\
\text { oxysporum }\end{array}$ & $\begin{array}{c}\text { Aspergillus } \\
\text { niger }\end{array}$ & $\begin{array}{c}\text { Aspergillus } \\
\text { flavus }\end{array}$ & $\begin{array}{c}\text { Aspergillus } \\
\text { terreus }\end{array}$ & $\begin{array}{l}\text { Aspergillus } \\
\text { fumigatus }\end{array}$ & $\begin{array}{c}\text { Macrophomina } \\
\text { phaseolina }\end{array}$ & $\begin{array}{l}\text { Phoma } \\
\text { sp. }\end{array}$ & Control & \\
\hline GM 3 & 7.13 & 4.75 & 6.13 & 4.55 & 6.48 & 7.20 & 4.25 & 7.48 & 8.00 & 6.21 \\
\hline GM 4 & 5.30 & 4.80 & 5.20 & 5.28 & 4.75 & 6.60 & 4.00 & 7.25 & 8.75 & 5.76 \\
\hline GAM 5 & 6.33 & 4.93 & 5.30 & 6.50 & 6.00 & 7.25 & 4.00 & 8.18 & 9.00 & 6.38 \\
\hline K 851 & 5.50 & 6.30 & 4.88 & 3.75 & 5.95 & 6.18 & 4.88 & 7.13 & 8.20 & 5.86 \\
\hline Meha & 5.08 & 4.05 & 3.75 & 4.33 & 5.25 & 5.68 & 2.63 & 5.55 & 7.00 & 4.81 \\
\hline \multirow[t]{2}{*}{ Mean $(F)$} & 5.86 & 4.96 & 5.05 & 4.88 & 5.68 & 6.58 & 3.95 & 7.11 & 8.19 & \\
\hline & $\mathbf{C}$ & $\mathbf{F}$ & C X F & & & & & & & \\
\hline $\mathrm{S} \mathrm{Em} \pm$ & 0.09 & 0.12 & 0.27 & & & & & & & \\
\hline $\mathrm{CD}$ at $5 \%$ & 0.26 & 0.35 & 0.77 & & & & & & & \\
\hline $\mathrm{CV} \%$ & 9.53 & & & & & & & & & \\
\hline
\end{tabular}

(Note: $\mathbf{C}=$ Cultivar, $\mathbf{F}=$ Fungi) 
Table.4 Seedling vigour index of mungbean cultivars as influenced by seed mycoflora

\begin{tabular}{|c|c|c|c|c|c|c|c|c|c|c|}
\hline \multirow[t]{3}{*}{ Cultivars } & \multicolumn{9}{|c|}{ Seedling vigour index } & \multirow{3}{*}{$\begin{array}{c}\text { Mean } \\
\text { (C) }\end{array}$} \\
\hline & \multicolumn{9}{|c|}{ Fungi } & \\
\hline & $\begin{array}{c}\text { Alternaria } \\
\text { alternata }\end{array}$ & $\begin{array}{l}\text { Fusarium } \\
\text { oxysporum }\end{array}$ & $\begin{array}{c}\text { Aspergillus } \\
\text { niger }\end{array}$ & $\begin{array}{c}\text { Aspergillus } \\
\text { flavus }\end{array}$ & $\begin{array}{c}\text { Aspergillus } \\
\text { terreus }\end{array}$ & $\begin{array}{l}\text { Aspergillus } \\
\text { fumigatus }\end{array}$ & $\begin{array}{c}\text { Macrophomina } \\
\text { phaseolina }\end{array}$ & $\begin{array}{c}\text { Phoma } \\
\text { sp. }\end{array}$ & Control & \\
\hline GM 3 & 552.25 & 305.00 & 432.13 & 308.75 & 441.50 & 547.90 & 285.25 & 591.85 & 725.90 & 465.61 \\
\hline GM 4 & 359.48 & 175.28 & 323.50 & 334.50 & 307.13 & 438.38 & 245.88 & 598.63 & 745.83 & 392.06 \\
\hline GAM 5 & 506.25 & 338.00 & 390.40 & 486.88 & 454.78 & 568.50 & 285.63 & 714.08 & 858.50 & 511.44 \\
\hline K 851 & 472.38 & 425.13 & 365.50 & 287.75 & 480.75 & 520.78 & 274.88 & 601.00 & 758.75 & 465.21 \\
\hline Meha & 279.13 & 186.13 & 217.00 & 208.50 & 370.25 & 418.83 & 58.00 & 412.40 & 572.13 & 302.48 \\
\hline \multirow[t]{2}{*}{ Mean $(F)$} & 433.90 & 285.91 & 345.71 & 325.28 & 410.88 & 498.88 & 229.93 & 583.59 & 732.22 & \\
\hline & $\mathbf{C}$ & $\mathbf{F}$ & C X F & & & & & & & \\
\hline $\mathrm{S} \mathrm{Em} \pm$ & 8.00 & 10.74 & 24.02 & & & & & & & \\
\hline $\mathrm{CD}$ at $5 \%$ & 22.19 & 29.77 & 66.58 & & & & & & & \\
\hline $\mathrm{CV} \%$ & 11.24 & & & & & & & & & \\
\hline
\end{tabular}

(Note: $\mathbf{C}=$ Cultivar, $\mathbf{F}=$ Fungi) 
Table.5 Per cent discoloration intensity of mungbean seedling as influenced by seed mycoflora

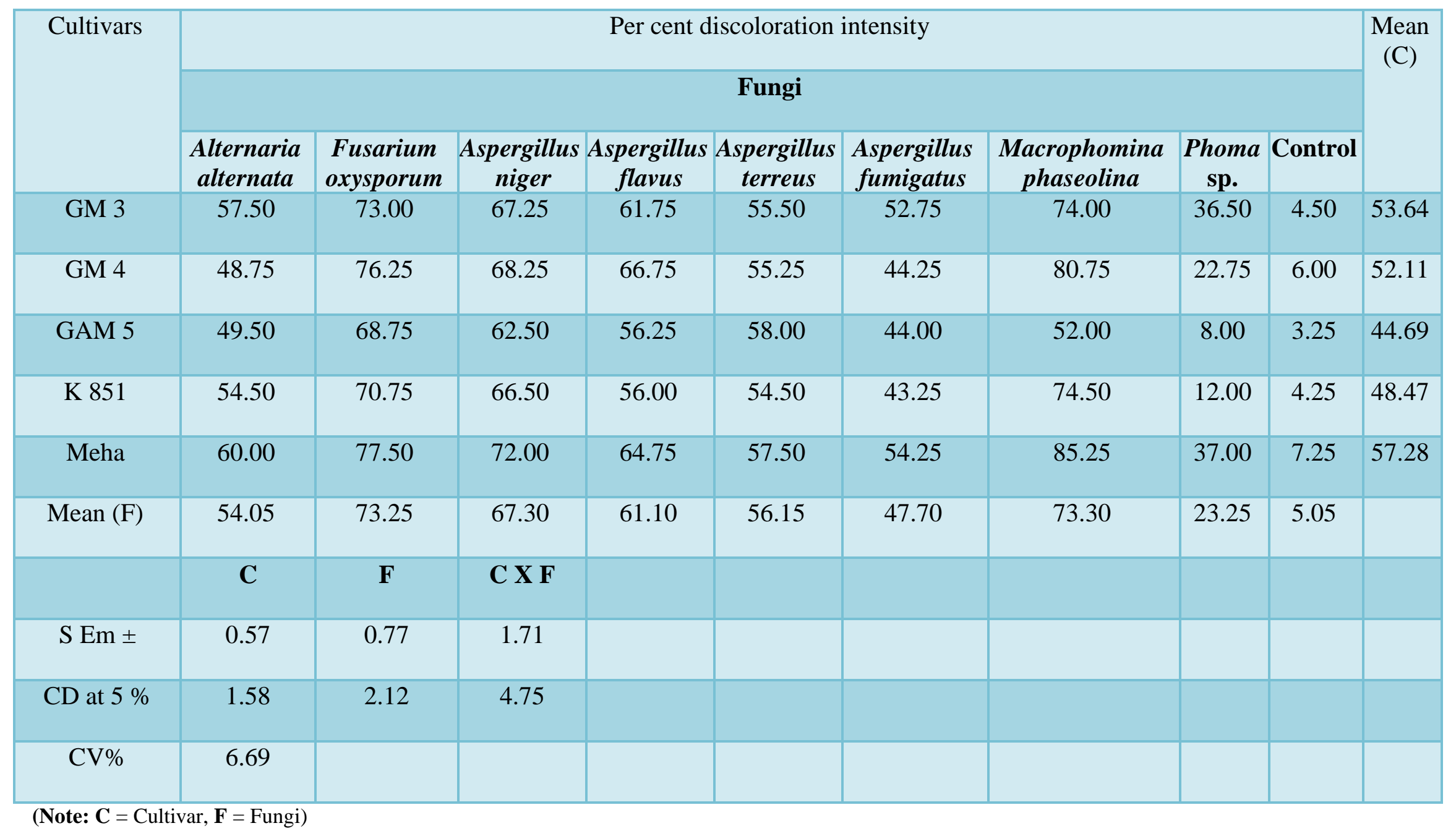


The lowest seedling vigour index was found in cultivar Meha (302.48) followed by cultivar GM 4 (392.066) and K 851 (465.21). Seed mycoflora and different cultivars were also significantly differed.

The lowest seedling vigour index was by Macrophomina phaseolina (58.0) followed by Fusarium oxysporum (186.13) in cultivar Meha. The highest seedling vigour index was found by Phoma sp. (714.08) in cultivar GAM 5. Among all tested fungus, seedling vigour index was highly influenced by Macrophomina phaseolina (229.93) followed by Fusarium oxysporum (285.91), Aspergillus flavus (325.28) and Aspergillus niger (345.71). Seedling vigour index was least affected by Phoma sp. (583.59) as compared to control (732.22). Similar result was found by Vasava (2017) who concluded that in respect of average SVI of five cultivars, Fusarium oxysporum showed the maximum detrimental effect thereby recorded minimum SVI (314.08) followed by Aspergillus niger (373.61) and Aspergillus flavus (444.27), while Aspergillus terreus (531.01) revealed the lowest adverse effect on SVI among eight seed mycoflora evaluated.

\section{Per cent discolouration intensity of mungbean seedlings}

Per cent discolouration intensity (PDI) was influenced by various seed mycoflora are presented in Table 5. Results indicated that per cent discolouration intensity in all mungbean cultivars was significantly differed from each other. The significantly highest per cent discolouration intensity was observed in cultivar Meha (57.28) followed by cultivar GM 3 (53.64) which was statistically at par with cultivar GM 4 (52.11). The lowest per cent discolouration intensity was found in cultivar GAM 5 (44.69). Results revealed that among all tested fungus, the highest per cent discolouration intensity was observed by Macrophomina phaseolina (73.30) which was statistically at par with Fusarium oxysporum (73.25). The lowest per cent discolouration intensity was observed by Phoma sp. (23.25) followed by Aspergillus fumigatus (47.70) and Alternaria alternata (54.05). Seed mycoflora and different cultivars was also significantly differ. The highest per cent discolouration intensity was observed by Macrophomina phaseolina (85.25) followed by Fusarium oxysporum (77.50) in cultivar Meha. The lowest per cent discolouration intensity was found by Phoma sp. (8.0) in cultivar GAM 5 as compared to control (3.25). Similar results were obtained by Vasava (2017) who reported that in respect of average PDI showing overall effects on seedling irrespective of cowpea cultivars. Rhizopus sp., Fusarium oxysporum, Aspergillus terreus, Aspergillus niger, Aspergillus flavus, Aspergillus fumigatus, Alternaria alternata and Macrophomina phaseolina showed PDI in between 51.37 to 69.36. The Fusarium oxysporum showed highest PDI in cultivars viz., GC 5 (75.83) and GC 4 (73.20). Rhizopus sp. showed significantly lowest per cent discoloration intensity in cultivar GDVC 1 (47.78), followed by AVCP 1 (48.13). Vaghela (2017) also reported that Aspergillus flavus showed highest PDI in groundnut cultivars viz., GG 8 (77.75), GG 2 (77.25) and GG 11 (75). Aspergillus terreus showed significantly lowest discolouration intensity in cultivar GG 20 (26.25) which was at par with GG 5(26.50). In respect of mean PDI showing overall effects on seedling irrespective of groundnut cultivars, Aspergillus niger, Aspergillus flavus, Fusarium oxysporum, Rhizopus sp., Aspergillus fumigatus, Aspergillus terreus showed PDI in between 33.42 to $69.55 \%$ in descending order.

\section{Acknowledgement}

This manuscript is the part of M.Sc. (Agri.) thesis work. Hence, the author is grateful to Department to Plant Pathology, B. A. College 
of Agriculture, Anand Agricultural University, Anand for providing necessary facilities.

\section{References}

Anonymous 2016. Crop production data green gram 2014-15.

Abdul Baki, A. and Anderson, J. D. 1973. Vigour determination in soybean seeds by multiple criteria. Crop Sci. 13: 630-633.

Bakr, M. A. and Rahaman, M. L. 2001. Research findings of BARI on seedborne disease on pulses. Proc. National Workshop on Seed Path. pp: 45-52.

Fakir, G. A., Hossain, I. and Parmanik, B. K. 2001. Research finding of BAU on seed borne diseases of pulses. Proc. National Workshop on seed Pathol. BAU. pp: 1-10.

I.S.T.A. 1985. International rules for seed testing. Seed Sci. Technol. 13: 307502.

Tsou, C. S., Hsu, M. S., Tan, S. and Park, H. G. 1979. Acta Hort. 93: 279-287.

Singh, H. B., Joshi, B. S. and Thomas, T. A. 1970. In kachroo, p. (ed.) pulse crops of India. New Delhi, ICAR.

Van Gastel, A. J. G. V., Pagnatta, M. A. and Porceddu, E. 1996. Studies on seed health testing techniques for pulses. Seeds Sci. Tech., ICARDA, Aleppo, Syria, pp: 289 - 295.
Wheeler, B. E. J. 1969. An introduction to plant diseases. John willey and Sons Ltd London: pp: 301.

Deshmukh, A. J. 2012. Investigation on seed mycoflora of green gram [Vigna radiata (L.) Wilczek.] and their management. (Master thesis, Navasari Agricultural University, Navasari, Gujarat).

Sadhu, K. A. 2014. Seed-borne fungi and their effect on seed health of green gram. Bioscience Discovery. 5 (2): 251-255.

Sinha, M. K. and Prasad, T. 1981. Effect of fungal metabolites on seed germination, microbial association and seedling growth of mung. Indian phytopath. 34 (4): 515-517.

Utobo, E. B., Ogbod, E. N. and Nwogbaga, A. C. 2011. Seed-borne mycoflora associated with rice and their influence on growth at Abakaliki, Southeast Agro-Ecology, Nigeria. Libyan Agric. Res. Center J. Int. 2 (2): 79-84.

Vaghela, K. D. 2017. Detection and management of seed mycoflora associated with groundnut cultivars. (Master thesis, Anand Agricultural University, Anand, Gujarat).

Vasava, K. I. 2017. Seed health status of cowpea [Vigna unguiculata (L.) Walp] and its management. (Master thesis, Anand Agricultural University, Anand, Gujarat).

\section{How to cite this article:}

Rameela I. Chaudhari, Vikram R. Gohel and Tarun K. Mandaviya. 2018. Effect of Seed Mycoflora on Mungbean Seed Health with Respect to Seed Germination and Seedling Vigour. Int.J.Curr.Microbiol.App.Sci. 7(07): 1967-1976. doi: https://doi.org/10.20546/ijcmas.2018.707.231 